\section{A Conceptual Model of the Relationship between Personal Values and Personal Tax Culture Regarding the Perception of Tax System Fairness}

\author{
Aleksandra Vehovar \\ PhD Student at the University of Maribor, Faculty of Economics and \\ Business, Slovenia \\ aleksandra.vehovar@student.um.si \\ Damijan Mumel \\ University of Maribor, Faculty of Economics and Business, Slovenia \\ damijan.mumel@um.si

\section{Lidija Hauptman} \\ University of Maribor, Faculty of Economics and Business, Slovenia \\ lidija.hauptman@um.si
}

\begin{abstract}
The purpose of this paper is to explore the relationship between personal values and personal tax culture regarding the perception of a tax system's fairness. The paper deals with the main theoretical starting points of the fundamental cornerstones of the general tax culture such as tax evasion, tax compliance and tax system. Based on findings in Schwartz's model of personal values, the paper discusses some of individual personal values, categorized into ten groups within a two-dimensional circular design, along two bipolar dimensions. Because this field of research is largely unexplored and based on the previous theoretical research, a conceptual model for analysing this relationship was developed.
\end{abstract}

Keywords: personal values, personal tax culture, tax system, tax compliance, conceptual model

\section{Introduction}

The behavior of an individual as a result of a set of personal values plays an important role in their studying (Bardi \& Schwartz, 2003, p. 1207). With their help, we understand various socio-psychological phenomena (Schwartz \& Bardi, 2001, as summarized from Bardi \& Schwartz, 2003, p. 1207). The relationship between personal values and personal tax culture is quite unexplored in the existing literature. We establish that there is an ungrounded relationship between personal values and personal tax culture regarding the perceptions of a tax system's fairness.

Therefore, the purpose of the paper is to examine the gap between personal values of two target groups, accountants and non-accountants, and their personal tax culture. The gap between them is illustrated in the paper with the help of
ORIGINAL SCIENTIFIC PAPER

RECEIVED: DECEMBER 2017

REVISED: FEBRUARY 2018

ACCEPTED: FEBRUARY 2018

DOI: 10.2478/ngoe-2018-0005

UDK: 336.221.4:17.022.1

JEL: M41, M48, M26

Citation: Vehovar, A., Mumel, D., \& Hauptman, L. (2018). A conceptual model of the relationship between personal values and personal tax culture regarding the perception of tax system fairness. Naše gospodarstvo/Our Economy, 64(1), 41-47. DOI: 10.2478/ ngoe-2018-0005

\section{NG OE}

NAŠE GOSPODARSTVO OUR ECONOMY

\begin{tabular}{l|l|l} 
Vol. 64 No. 12018 \\
\hline
\end{tabular}

pp. $41-47$ 
a conceptual model for analyzing the relationship between personal values and personal tax culture, regarding the perception of a tax system's fairness.

The introductory part is followed by a shorter theoretical presentation of the problem, followed by the development of the conceptual model and research questions with responses to them.

\section{Personal Tax Culture: Literature Review}

Despite a still unfounded relationship between the personal values of accountants and non-accountants and their personal tax culture, personal values were already studied by many authors in the past. Feldman (2015), Schwartz (1992), Sezer et al. (2015), Litina and Palivos (2016), Gino (2015), Alleyne et al. (2013), Fischer and Poortinga (2012), Fischer, et al. (2010), and Vauclair et al. (2015) studied factors influencing the shaping of individuals and consequently their personal culture. They established that personal values were supposed to have the key role in motivating for ethical decision and behaviour of individuals. An important milestone in studying personal values was set by Schwartz (1992), as he measured the importance of an individual's personal values with the help of a questionnaire in many variants with different chosen populations. Hofstede (1980, in Richardson, 2007, 2008) studied dimensions of national culture, which indirectly influence the formation of tax culture.

Due the too broad range of individual cornerstones of tax culture, we limit the scope of our study to only some, namely: tax system, tax evasion, tax compliance and personal values.

The first cornerstone of personal culture, tax system, is according to Richardson (2007, p. 62), an entirety of important factors in comprehension of tax culture. Richardson (2007, p. 62) thinks that a tax system should be efficient, open, measurable and dividable; it presents an entirety of tax formats in specific countries with the purpose to fulfil fiscal, economic and social goals. Tax legislation is not always sufficiently precise and, therefore, there are often tax gaps (James \& Alley, 2004, p. 29). There are practical difficulties in interpreting and understanding tax legislation, since the state and taxpayers do not have the same interpretation or tax discipline (James \& Alley, 2004, p. 29).

The extent in which taxpayers challenge the significance of the tax law may depend on numerous things, including the level of their preparedness to act in accordance with the existent tax system (James \& Alley, 2004, p. 30). Richardson (2007), Mayr (2000), Jackson and Milliron (1986), and
Richardson and Sawyer (2001) state different definitions of the desired characteristics of tax systems. Richardson (2007, p. 62) emphasises simplicity. The simplicity of a tax system as a cornerstone of tax culture is an important factor in studying tax evasion (Jackson \& Milliron, 1986, p. 138; Richardson \& Sawyer, 2001, p. 184; as summarized from Richardson, 2006, p. 153). The tax system influences tax values, which are influenced by individual cultural dimensions defined by Hofstede (individualism, patriarchism, avoiding uncertainty, and influence / power of an individual), and external factors. Based on these intertwining factors, Richardson (2007) examined in an empirical study the relationship between the already mentioned four cultural dimensions according to Hofstede and other components of the entire tax system, such as external influences, legal consequences, tax system, tax values and accounting system.

The second cornerstone of tax culture is tax evasion. According to Mangoting et al. (2015, p. 966), tax evasion is breaching legal provisions; rationally, taxpayers think they should have benefits from paying taxes. In literature, many authors defined the concept of tax evasion and it was the subject of numerous researches, as well (McGee, 2005a; 2005b; 2006; 2006a; 2007; Richardson, 2006; Richardson, 2008; Tsakumis, 2007; Cule, 2009; Korndörfer, 2014; Webley, 2001; Torgler, 2003; Pickhardt, 2014; Ahmed \& Braithwaite, 2005; Alm, 2012a; Alm, 2012b; Coricelli et al., 2014; Falkinger \& Walther, 1991; Marino \& Zizza, 2012; Mittone \& Patelli, 2000; Pickhardt \& Seibold, 2014). Authors study traditional (Alm, 2012a; 2012b; Alm \& Murray, 1991; Alm \& Melnik, 2010) as well as modern approaches to measuring tax evasion (Alm, 2012a; 2012b; Slemrod, Blumenthal \& Christian, 2001; Kleven, Knudsen, Kreiner, Pedersen \& Saez, 2010; Iyer, Reckers \& Sanders, 2010; Pissardies \& Weber; 1989; Feldman \& Slemrod, 2007; Henderson, Storeygard \& Weil, 2009). Hofstede (1980, p. 25; Richardson, 2008, p. 69; Richardson, 2006) was the first one to draw attention to interconnectivity between a national culture and related tax culture and tax evasion.

Among important factors that connect and influence tax processes (tax evasion and tax culture), there is also tax compliance. James and Alley (2004, p. 29; as summarized from Andreas \& Savitri, 2015, p. 165) believe that tax compliance is problematic, as it is not always easy to convince a taxpayer to act in accordance with law and to fulfil tax liabilities. Thus, Zain (2007, p. 45; as summarized from Mangoting et al., 2015, p. 966) realized that one of the bigger problems of low tax compliance in the country is high tax evasion. According to James and Alley (2004, p. 29), the simplest definition of tax compliance is the extent in which taxpayers act in accordance with tax legislation. Besides the stated, the concept and measurement of the phenomena of tax compliance, which includes the tax activity 
and means that tax activities in the country as well as outside of it are reciprocally tax compliant, were also studied by Andreas and Savitri (2015), Bayissa Gobena and Van Dijke (2016), Saad (2014), Kastlunger, Dressler and Kirchler (2010), Lisi (2014; 2015), Liviu Mesca (2013), Kornhauser (2007), Andreoni, Erard and Feinstein (1998), James \& Alley (2004), Hofmann, Hoelzl and Kirchler (2008), Harter, Rechberger, Kirchler and Schabmann (2008), Kastlunger, Kirchler, Mittone and Pitters (2009), and Hofmann, Hoelzl and Kirchler (2008). Regardless of the chosen width of the justification of the concept of tax compliance, the level of tax compliance can be measured through various factors that influence its development.

Defining the chosen cornerstones of tax culture indicates intertwinement of different factors with reciprocal influence. If we wish to analyse the relationship between the personal values of an individual and his/her tax culture, we must study his/her personal values, as well. The personality of an individual includes all physical, mental and behavioural characteristics, which appear relatively constantly and distinctively in an individual (Musek \& Pečjak, 2001, p. 188). Feldman and co-authors (2015) proved the complexity of motives for unethical behaviour regarding motivating people to act ethically or unethically. They emphasized the importance of understanding the motivation linked to unethical behaviour (Kish-Gephart, Harrison \& Trevino, 2010; Pulfrey \& Butera, 2013; Tenbrunsel \& Smith-Crowe, 2008; Trevino, Weaver \& Reynolds, 2006; as summarized from Feldman et al., 2015, p. 1). In making their choices, people act in accordance with their own interests (Feldman, 2015, p. 69). They calculate in themselves the probability that their behavior will have various consequences and probabilities (Brlic, 2010, page 18). They usually choose those actions that maximize the positive results and minimize the negative ones. Personal values are an abstract, long-term motivational goal and reflect the principles and beliefs of a person about what matters to him/her in life (Schwartz, 1992; Feldman et al., 2015, p. 70).

\section{A Conceptual Model of the Relationship between Personal Values and Personal Tax Culture}

With the help of the conceptual model, the so-far existing theoretical as well as empirical findings where gaps are presented in the existing literature will be presented. Within the conceptual model, four different sets of relationships in Figure 1 will be presented. Individual variables of the model, were already presented theoretically as well as empirically in some previous researches, as mentioned in the previous chapter. Schwartz (1992) divided ten motivational types of values in two bipolar dimensions - self-enhancement and self-transcendence on one hand, and openness to change and conservatism on the other. Therefore, in the model of relationships, we divided the latter into four different sets (See Figure 1). Each of these sets includes a component of one bipolar dimension of personal values relationship of which we then study with all three chosen cornerstones of personal tax culture-tax compliant behaviour, attitude of ethicality toward tax evasion and attitude toward tax system. These were taken from the definition of the general tax culture on the macro level and will now be studied on the level of an individual.

Figure 1. Conceptual model - presentation of relationships

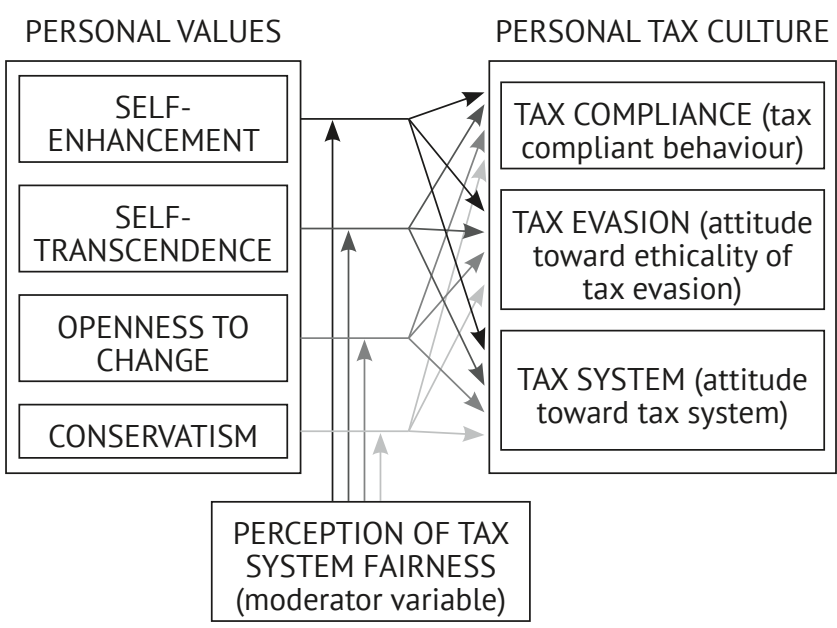

Source: Own research, 2017.

The concept of tax evasion, which is measured with the attitude toward ethicality of tax evasion, is included into the conceptual model due to unethicality of tax evasion in a certain environment, which can also be studied as a socially responsible or irresponsible behaviour. Tax evasion is measured with the help of the already developed instrument used by McGee (2006). The concept of tax compliance is measured with the help of an individual's attitude toward tax compliant behaviour.

Tax compliance, interpreted as a level of individual's preparedness or the social responsibility of an individual to fulfil tax liabilities, is an important factor that connects and influences tax processes. A tax system is one of the cornerstones of tax culture, which is researched in relationship with the personal values of an individual via individual's attitude to the existing tax system; hereby the individual's social responsibility is noticeable again. In relationship with the tax system we included in the model a moderator variable, i.e., the individual's perception of tax system fairness. 
We namely conclude that an individual acts differently in circumstances for which they believe that the tax system toward them as taxpayers is fair than in circumstances about which they believe that the tax system toward them is unfair. Personal values of an individual were included in the model as Feldman (2015) studied how personal values of an individual actually influence unethical behaviour.

Feldman (2015) states that the dimension of self-enhancement emphasizes the encouragement of oneself and encouragement of selfish interests at the expense of others. Therefore, the values included in the dimension of self-enhancement present a danger of a high level of unethicality. The assumption is that the perception of a tax system's fairness influences the intensity of the relationship between self-enhancement and individual cornerstones of tax culture (the individual's attitude toward the tax system, the individual's attitude toward ethicality of tax evasion and the individual's tax compliant behaviour).

The dimension of self-transcendence promotes the interests of others (Feldman, 2015). Values in this dimension state motivation for empathy, fairness and integrity toward others (Grant, 2007; 2008; as summarized from Feldman, 2015). In this way, the dimension of self-transcendence reflects a negative attitude toward unethicality that includes harm of others (Schwartz, 2007; Sverdlik et al., 2012; as summarised from Feldman, 2015). The assumption is that the perception of tax system fairness influences the intensity of relationship between self-transcendence and individual cornerstones of tax culture (the individual's attitude toward the tax system, the individual's attitude toward ethicality of tax evasion and the individual's tax compliant behaviour).

The dimension of personal values called openness to change reflects the openness of thinking and behaviour and includes stimulation and promotion of interests of an individual (Schwartz, 1992). Out of all four dimensions, this is the one that is the least directed in unethicality in its proportion, as unethicality in this context is mostly dependent on the individual's motif. There is an assumption that the perception of a tax system's fairness influences the intensity of the relationship between openness to change and individual cornerstones of tax culture (the individual's attitude toward the tax system, the individual's attitude toward ethicality of tax evasion and the individual's tax compliant behaviour).

Personal values, which include tradition, safety and compliance of an individual's behaviour in accordance with expectations, express motivation for self-discipline and present a person's overcoming his/her immediate wishes (Feldman, 2015). We assume that the perception of a tax system's fairness influences the intensity of the relationship between conservatism and individual cornerstones of tax culture (the individual's attitude toward the tax system, the individual's attitude toward ethicality of tax evasion and the individual's tax compliant behaviour).

\section{Research Questions Based on the Conceptual Model}

Based on the existing literature and previous research that has dealt with the topic, the following research questions arise:

\section{- Is there a connection between personal values of an individual and tax evasion?}

We find the answer on this researched question to be that the personal values of an individual are a sum of his/her physical, mental and behavioral characteristics, which are characteristic of him/her (Musek \& Pečjak, 2001, p. 188). Individuals calculate in themselves the probability that due to their behavior, there will be various consequences and they calculate the likelihood of those as well (Brlic, 2010, p. 18). They usually decide on those actions that maximize the positive results and minimize the negative ones. At some points in life, ethics can be learnt. People are not born with innate desires to be ethical or to care for the welfare of others (Brlic, 2010, p. 18). Individual values depend on the environment in which individuals live and on the prevailing social, cultural and economic factors. Feldman and co-authors (2015) explore the reasons for the unethical behavior of individuals. They studied the connection between personal values and unethical attitudes and behavior. They proved the complexity of motives for unethical behavior, as to motivating people to act ethically or unethically. They emphasized the importance of understanding the motivation associated with unethical behavior (Kish-Gephart, Harrison \& Trevino, 2010; Puffrey \& Butera, 2013; Tenbrunsel \& Smith-Crowe, 2008; Trevino, Weaver \& Reynolds, 2006; Feldman et al. 2015, p. 1). Rest and Barnett (1986, Feldman et al., 2015, p. 70) identified non-ethics as a violation of generally accepted socio-ethical norms. Such behavior can include lies, dishonesty, fraud, theft, sabotage, and bribery. It may also include less active unethical behavior, such as other concealment and violation of legislation (Feldman et al., 2015, p. 70). On the other hand, there is a cornerstone of tax culture: tax evasion, defined as an impermissible, immoral and criminal act. Several authors studied the motives of an individual for his/her tendency to tax evasion. Hundsdoerfer (1996, p. 18) lists numerous individual's motives, which are the result of the personality of each individual. With the theoretical findings and the current research in the field of personal values and tax evasion, we can claim that there is a connection between personal values of the individual and the individual's inclination to tax evasion, which originates from the personality of the individual. 
- Is there a connection between personal values of an individual and tax compliance?

Tax compliance is measured by the individual's attitude towards tax compliance. Tax compliance, which is interpreted as the degree of readiness of an individual to fulfill tax obligations, is an important factor that links and affects tax processes. James and Alley (2004, p. 29) state that the simplest definition of tax compliance is to be understood as the degree to which taxpayers operate in accordance with tax legislation. Tax compliance was the subject of both theoretical and empirical studies, but never in connection with personal values defined by Schwartz (1992). James \& Alley (2004, p. 29, summarized by Andreas \& Savitri, 2015, p. 165) state that tax compliance is problematic because it is not always easy to persuade the taxpayer to act in accordance with the law and to comply with tax obligations. Thus, various authors (Zain, 2007, p. 45, summarized by Mangoting et al., 2015, p. 966) concluded that one of the major problems of low tax compliance in the country is high tax evasion. Thus, we can conclude that there is also a positive connection between personal values of an individual and their tax compliance, since this is a consequence of an individual's personality.

\section{Conclusion}

According to the review of scientific literature on the main cornerstones, included in the developed model for analyzing the relationship between personal values of the individual and the personal tax culture, in view of the perception of the tax system fairness, both the theoretical and the empirical gap in the field of research are perceived. The increasing importance of personal values, which are physical, mental and behavioral characteristics by which individuals differ from one another, affects the socially responsible behavior of an individual. In the literature, though, there are no studies of the connection of personal values with an individual's personal tax culture. That is why we designed a conceptual model that would include both the individual's tax culture, as well as personal values of the individual. In their work, individual authors have already been defining and empirically proving individual cornerstones of tax culture, especially at the macroeconomic level; the developed model, however, connects all the cornerstones with personal values. In further research, empirical research can be carried out on the basis of a conceptual model and a designed questionnaire in several different countries. Therefore, a comparison of the results of individual countries will be possible.

\section{References}

Ahmed, E. \& Braithwaite, V. (2015). A need for emotionally intelligent policy: Linking tax evasion with higher education funding. Legal and Criminological Psychology, 10, 291-308. https://doi.org/10.1348/135532505X37263

Alleyne, P., et al. (2013). Examining personal values and ethical behaviour perceptions between accounting and non-accounting students in the Caribbean. The Accounting Educators Journal, 23, 47-70.

Andreas, Savitri E. (2015). The effect of tax socialization, tax knowledge, expediency of tax ID number and service quality on taxpayers' compliance with taxpayers' awareness as mediating variables. Social and Behavioral Sciences, 211, 163-169. https://doi. org/10.1016/j.sbspro.2015.11.024

Bardi, A., \& Schwartz, S. H. (2003). Values and behavior: Strength and structure of relations. Personality and Social Psychology Bulletin, 29 (10), 1207-1220. https://doi.org/10.1177/0146167203254602

Feldman, G., Manchi Chao M., Farh J. L. \& Bardi A. (2015). The motivation and inhibition of breaking rules: Personal values structures predict unethicality. Journal of Research in Personality, 59, 69-80. https://doi.org/10.1016/j.jrp.2015.09.003

Fischer, R., \& Poortinga, Y. H. (2012). Are cultural values the same as the values of individuals? An examination of similarities in personal, social and cultural value structures. International Journal of Cross Cultural Management, 12(2), 157-170. https://doi. org/10.1177/1470595812439867

Hofstede, G. H. (1980). Cultures consequences: International differences in work-related values. In Bevery Hills. CA: Sage Publications.

Jackson, B. R., \& Milliron, V. C. (1986). Tax Compliance research: Findings, problems and prospects. Journal of Accounting Literature, 5 , 125-165.

Kastlunger B., Dressler S. G., Kirchler E., Mittone L., Voracek. (2010). Sex differences in tax compliance: Differentiating between demographic sex, gender-role orientation, and prenatal masculinization. Journal of Economic Psychology, 31, 542-552. https://doi. org/10.1016/j.joep.2010.03.015

Korndörfer, M. (2014). Measuring and explaining tax evasion: Improving self-reports using the crosswisse model. Journal of Economic Psychology, 45, 18-32.

Kornhauser, M. E. (2007). Normative and cognitive aspecs of tax compliance. Literature review and recommendations for the IRS regarding individual taxpayers. Annual Report to Congress 138. National Taxpayer Advocate, 2, 138-180.

Litina, A., \& Palivos, T. (2016). Corruption, tax evasion and social values. Journal of Economic Behaviour \& Organization, 124, $164-177$. https://doi.org/10.1016/j.jebo.2015.09.017

McGee W. Robert. (2005a). The ethics of tax evasion: A survey of Guatemalan opinion. In: Taxation and Public Finance in Transition and Developing Economies (pp. 481-895). Springer: Boston. 
McGee, W. R. (2005b). The ethics of tax evasion: A survey of Romanian business students and faculty. In: Accounting and Financial Systems Reform in Eastern Europe and Asia (pp. 299-334). Springer: Boston. https://doi.org/10.2139/ssrn.813345

McGee, W. R. (2006). Tax evasion in Armenia: An empirical study. Social Science Research Network - SSRN, 2006. https://doi.org/10.2139/ ssrn.869309

McGee, W. R. (2006a). The ethics of tax evasion: A survey of Bosnian opinion. Social Science Research Network - SSRN, 2006.

McGee, W. R. (2007). Ethics, tax evasion and age: Empirical studies of opinion in Utah and 14 countries in the Western Hemisphere. Social Science Research Network - SSRN, 2007. https://doi.org/10.2139/ssrn.960114

Musek, J. \& Pečjak, V. (2001). Psihologija. Ljubljana: Educy.

Nerre, B. (2001). The concept of tax culture. Proceedings. Annual Conference on Taxation and Minutes of the Annual Meeting of the National Tax Association. 94, 288-295.

Pickhardt, M. (2014). Behavioral dynamics of tax evasion - A survey. Journal of Economic Psychology, 40, 1-19. https://doi.org/10.1016/j. joep.2013.08.006

Richardson, G. (2006). Determinants of tax evasion: A cross-country investigation. Journal of International Accounting, Auditing and Taxation, 15 (2), 67-78. https://doi.org/10.1016/j.intaccaudtax.2006.08.005

Richardson, G. (2007). The influence of culture on tax systems internationally: A theoretical and empirical analysis. Journal of International Accounting Research, 6 (1), 57-79. https://doi.org/10.2308/jiar.2007.6.1.57

Richardson, G. (2008). The relationship between culture and tax evasion across countries: Additional evidence and extensions. Journal of International Accounting, Auditing and Taxation, 17 (2), 67-78. https://doi.org/10.1016/j.intaccaudtax.2008.07.002

Saad, N. (2014). Tax knowledge, tax complexity and tax compliance: Taxpayers' view. Social and Behavioral Sciences, 109, $1069-1075$. https://doi.org/10.1016/j.sbspro.2013.12.590

Schwartz, S. H. (1992). Universals in the content and structure values: Theoretical advances and empirical test in 20 countries. Advances in Experimental Social Psychology, 25 (1), 1-65. https://doi.org/10.1016/S0065-2601(08)60281-6

Schwartz, S. H. (1994). Are there universal aspects in the structure and contents of human values? Journal of Social Issues, 50(4), $19-45$. https://doi.org/10.1111/j.1540-4560.1994.tb01196.x

Schwartz, S. H., \& Bardi, A. (2001). Value hierarchies across cultures: Taking a similarities perspective.Journal of Cross-Cultural Psychology, 32 (3), 268-290. https://doi.org/10.1177/0022022101032003002

Schwartz, S. H. (2011). Studying values: Personal adventure, future directions.Journal of Cross-Cultural Psychology, 42(2), 307-319. https:// doi.org/10.1177/0022022110396925

Schwartz, S. H. (2012). An overviw of the Schwartz theory of basic values. Online Readings in Psychology and Culture, 2(1), 1-20. https:// doi.org/10.9707/2307-0919.1116

Torgler, B. (2003). To evade taxes or not to evade:That is the question.Journal od Socio-Economics, 32(3), 283-302. https://doi.org/10.1016/ S1053-5357(03)00040-4

Tsakumis, T. G. et al. (2007). The relationship between culture and tax evasion. Journal of International Accounting, Auditing and Taxation, 16(2), 131-147. https://doi.org/10.1016/j.intaccaudtax.2007.06.004

Vauclair, C. M., et al. (2015). What kinds of value motives guide people in their moral attitudes? The role of personal and prescriptive values at the culture level and individual level. Journal of Cross-Cultural Psychology, 46(2), 211-228. https://doi. org/10.1177/0022022114557487

Webley, P., Cole, M. \& Eidjar, O. P. (2001). The prediction of self-reported and hypothetical tax-evasion: Evidence from England, France and Norway. Journal of Economic Psychology, 22(2), 141-155. https://doi.org/10.1016/S0167-4870(01)00026-5

Woro Damayanti, T., Sutrisno, Subekti, I. \& Baridwan, Z. (2015). Trust and uncertainty orientation: An effort to create tax compliance in a social psychology framework. Procedia - Social and Behavioral Sciences, 211, 938-944. https://doi.org/10.1016/j.sbspro.2015.11.124

\section{Authors}

Aleksandra Vehovar is a PhD Student at the University of Maribor, Faculty of Economics and Business, Department of Accounting, Auditing and Taxation. She received her master's degree in economic and business sciences from the University of Maribor, Faculty of Economics and Business in September 2015. Her current research interests are in a field of taxation, accounting and auditing.

Damijan Mumel works as a Professor of marketing at the University of Maribor, Faculty of Economics and Business and a Head of Marketing institute. His main areas of research interest and lecturing are consumer behaviour, research methodology, qualitative research and communication. He presents his work at international scientific conferences and publishes original scientific papers in domestic and foreign scientific journals. He is a member of the Slovenian Marketing Association and the Slovenian Psychologists' Association, as well as the European Marketing Academy (EMAC). 
Lidija Hauptman is an associated professor of accounting, taxation and auditing at the University of Maribor, Faculty of Economics and Business. She received her PhD from the University in Maribor. Her current research interests are in a field of taxation, accounting and auditing. She received a Marie Curie fellowship in 2004 at the Department of Austrian and International Tax Law at the Vienna University of Economics and Business. She also received Diplomas in special bachelor programmes from St. Gallen University and Vienna University of Economics and Business.

\section{Konceptualni model povezav med osebnimi vrednotami in osebno davčno kulturo glede na percepcijo pravičnosti davčnega sistema}

\section{Izvleček}

Namen prispevka je raziskati povezavo med osebnimi vrednotami in osebno davčno kulturo glede na percepcijo pravičnosti davčnega sistema. Prispevek obravnava glavne gradnike davčne kulture, kot so davčna utaja, davčna usklajenost in davčni sistem. Na drugi strani pa teoretično opredeljujemo osebne vrednote posameznika, pri katerih smo se usmerili na Schwartzov model osebnih vrednot. Schwartzov model osebne vrednote kategorizira v deset skupin, znotraj dvodimenzionalnega krožnega modela, vzdolž dveh bipolarnih dimenzij. Zaradi neraziskanosti obravnavanega področja smo v nadaljevanju prispevka razvili konceptualni model za analizo povezave med osebnimi vrednotami in osebno davčno kulturo, ki temelji na predhodnih raziskavah.

Ključne besede: osebne vrednote, osebna davčna kultura, davčni sistem, davčna skladnost, konceptualni model 